\title{
Role of Information Sharing on the Impact of Foreign Banks' Penetration on Banking Competition
}

\author{
Azadeh ZOHREHVAND', Saifuzzaman IBRAHIM², Muzafar Shah HABIBULLAH³, \\ Zulkornain YUSOP ${ }^{4}$, Nur Syazwani MAZLAN ${ }^{5}$
}

Received: August 01, 2020 Revised: October 11, 2020 Accepted: October 15, 2020

\begin{abstract}
Globalization has led to an increase in foreign banks' penetration. It is argued that the presence of foreign banks may affect the banking sector of the host countries in several ways including their competition level. It is mentioned that the presence of the foreign banks could heightened the level of competition in the banking sector. Nonetheless, the impact of the foreign banks on competition could be influenced by the degree of information sharing in the banking industry. This study investigates the role of information sharing in moderating the impact of foreign bank penetration on host banking sector competition in selected developing countries. We employ panel data samples of 54 developing countries during the period from 1998 to 2016. The estimation is carried out using the two-step system of the Generalized Method of Moments (GMM) regression technique. This technique is adopted due to its robustness to all forms of endogeneity. The findings of this study show that the presence of information sharing could affect the relationship between foreign banks' penetration and competition. They suggest that improvement in information sharing by a host country may help foreign banks to improve monitoring and reduce the moral hazard and adverse selection problem.
\end{abstract}

Keywords: Foreign Banks' Penetration, Information Sharing, Banking Competition, Generalized Method of Moments

JEL Classification Code: G21, G28, F20, F23

\section{Introduction}

The process of globalization has been growing steadily in most economies since the mid-1980s and has accelerated in developing countries in the 2000s. Especially during the period 2006 to 2007, the presence of foreign banks through globalization has seen a significant increase with a need

${ }^{1}$ First Author. School of Business and Economics, Universiti Putra Malaysia, 43400 Serdang, Selangor, Malaysia

${ }^{2}$ Corresponding Author. Associate Professor, School of Business and Economics, Universiti Putra Malaysia, Selangor, Malaysia [Postal Address: Jalan Universiti 1 Serdang, 43400 Seri Kembangan, Selangor, Malaysia]

E-mail: saifuzzaman@upm.edu.my; saifuzza74@yahoo.com

${ }^{3}$ School of Business and Economics, Universiti Putra Malaysia, 43400

Serdang, Selangor, Malaysia

${ }^{4}$ School of Business and Economics, Universiti Putra Malaysia, 43400

Serdang, Selangor, Malaysia

${ }^{5}$ School of Business and Economics, Universiti Putra Malaysia, 43400

Serdang, Selangor, Malaysia

(c) Copyright: The Author(s)

This is an Open Access article distributed under the terms of the Creative Commons Attribution Non-Commercial License (https://creativecommons.org/licenses/by-nc/4.0/) which permits unrestricted non-commercial use, distribution, and reproduction in any medium, provided the original work is properly cited. for immediate recapitalization and restructuring (Claessens \& Van Horen, 2012). Given the removal of entry-barriers for foreign banks and the existence of profit opportunities in developing economies, foreign ownership in financial institutions has increased in the domestic banking sector. Among developing countries, the number of foreign banks increased from 330 in 1995 to 569 in 2009, with the market share doubling from 18 percent to 36 percent during the same period. However, the number of domestic banks declined from 1456 in 1995 to 1001 in 2009 (Claessens \& Van Horen, 2012). As a result, most developing countries have opened their doors to foreign counterparts to help improve their capital, technology, bank competition, and efficiency.

The rising trend of foreign bank penetration has dropped sharply following the advent of the financial crisis. Although the penetration of foreign banks was regarded as favorable where costs are believed to outweigh the benefits, the effect of the recent global financial crisis has shaken this consensus. Growing disputes remain ambiguous regarding the costs and benefits resulting from foreign bank penetration. The precise impact of foreign banks on the economy is difficult to determine, and many host countries face the dilemma of whether to limit foreign bank penetration or give incentives 
to attract more entry. As a result, policymakers have been paying close attention to the impact of foreign bank penetration in developing countries.

The presence of foreign banks has raised many concerns about the possible impact on competitiveness in the hostbanking sector. The banks' anti-competitive forces tend to have huge implications on consumer welfare, productivity, stability, and economic growth. Recent empirical evidence suggested that the evaluation of competition based on firms' observed behavior could be derived from theoretical models of price and output determination (Bikker \& Haaf, 2002; Bikker et al., 2012; Claessens \& Leaven, 2004; Goddard \& Wilson, 2009; Jeon et al., 2011; Pisedtasalasai \& Edirisuriya, 2020; Purwono et al., 2019). Increasing competition brings several advantages, such as the increase in credit supply and the efficiency of domestic banks. Despite these benefits, foreign bank penetration in the domestic market still poses other disadvantages, including the reduction of domestic access to credit due to information asymmetries (Clarke et al., 2002). Consequently, foreign banks may also adopt cherry-picking practices due to the high costs of information acquisition (Sengupta, 2007; Claessens, 2017; Choi \& Kim, 2020). Considering their limited access to information regarding their customers, opaque and non-transparent customers for domestic banks are prevalent (Gormley, 2007). Increased competition from foreign bank penetration will adversely affect the ability of domestic banks to finance this type of customer. This can hurt domestic banks' asset quality and eventually leads to reduced competitiveness (Jeon et al., 2011). There is a definite possibility that foreign banks may increase the likelihood of a crowding-out effect among domestic banks and drive domestic banks to go out of business through comparative advantages (Jeon et al., 2011; Song, 2004).

One of the crucial disadvantages for foreign banks is asymmetric information (Beck et al., 2018). This makes foreign banks less willing to extend credit in host markets and forces them to concentrate on a top and selected segment of the market. This problem increases the incidence of adverse selection and moral hazards. The problem of asymmetric information can be resolved via the information sharing mechanism. Information sharing helps banks in three aspects: (a) it improves banks' knowledge regarding the borrower's characteristics to predict their repayment probability; (b) it reduces the informational rents due to making the market more competitive; (c) it stimulates borrowers' incentives to perform better through a disciplinary effect (Jappelli \& Pagano, 2002). Therefore, depth of information sharing will help foreign banks penetrate host countries and may change their effect on host competition.

Thus, this study aims to examine the role of information sharing on the impact of foreign banks' penetration on banking competition. Although the foreign banks' penetration-banking competition nexus has been previously tested, to the best of our knowledge, no study has examined the impact of information sharing on this nexus. Further, this study is important because the results are beneficial to the governments and policymakers for better and more accurate decision-making in welcoming foreign banks into their countries.

\section{Methodology and Data}

The study applies Claessens and Laeven (2004) model to investigate the effect of foreign banks on competition. The original equation of Claessens and Laeven (2004) is specified as follows:

$$
\text { Competition }_{i}=X_{i}^{\prime} b+\varepsilon_{i}
$$

where Competition ${ }_{i}$ is the measure of degree of banking competition for country $i$ and $X_{i}$ is vector of country-specific characteristics for country $i$. We estimate the following equation by employing the Generalised Method of Moments (GMM):

$$
\begin{aligned}
\ln \left(\text { Lerner }_{i t}\right) & =\alpha+\beta_{0} \ln \left(\text { Lerner }_{i t-1}\right)+\beta_{1} \text { foreign } \\
& \text { banks penetration } \\
& +\beta_{2} C R 5_{i t}+\beta_{3}(\text { foreign } \\
& \text { banks penetration } \left._{i t} \times C D I_{i t}\right)+\beta_{4}\left(C D I_{i t}\right) \\
& +\beta_{5}\left(\text { Activity restriction }_{i t}\right)+\beta_{6}\left(S M C_{i t}\right) \\
& +\beta_{8}\left(\text { GDPPC }_{i t}\right)+\varepsilon_{i t}
\end{aligned}
$$

where the $i$ is country level, and $t$ is time. The descriptions of each variables are presented in Table 1.

This study employs an unbalanced panel dataset of 54 developing countries during the period between 1998-2016. The panel covers the four-years spans: 1998-2001, 20022005, 2006-2009, 2010-2013 and 2014-2016 by taking no overlapping data. The sample includes all major countries in all continents that considerably open their doors to foreign banks' entry. The choice of variables reflects bank behavior through the banking sectors of developing countries.

The dependent variable is measured by the Lerner index to measure market competition inversely as market power in the banking sector because less competition implies greater market power. The Lerner index, a frequently-used measure of market power in banking is defined as the difference between output prices $(P)$ and marginal costs $(M C)$ relative to prices $(P-M C) / P$. The advantage of the Lerner Index is that it is not a long-run equilibrium measure of competition and can be calculated at each point in time. This study uses data that originated from the Global Financial Development Database $(G F D D)$ in 2019, which is built on the methodology described in Demirgüç-Kunt and Martínez Pería (2010) Higher values of the Lerner index indicate less bank competition. Some previous studies that employ Lerner index as a measure of the level of competition are those by Berger et al. (2009), and Agoraki et al. (2011). 
Table 1: Data Description

\begin{tabular}{|l|l|l|}
\hline Variable & \multicolumn{1}{|c|}{ Measurement } & \multicolumn{1}{c|}{ Source Of Data } \\
\hline $\begin{array}{l}\text { Lerner } \\
\text { (first proxy of banking } \\
\text { competition) }\end{array}$ & $\begin{array}{l}\text { The inverse measure of the degree of banking } \\
\text { competition based on individual country data }\end{array}$ & $\begin{array}{l}\text { Global Financial Development } \\
\text { Database (2019) }\end{array}$ \\
\hline $\begin{array}{l}\text { Boone indicator } \\
\text { (second proxy of banking } \\
\text { competition) }\end{array}$ & $\begin{array}{l}\text { A measure of the degree of competition based on } \\
\text { profit-efficiency in the banking market. It is calculated } \\
\text { as the elasticity of profits to marginal costs }\end{array}$ & $\begin{array}{l}\text { Global Financial Development } \\
\text { Database (2019) }\end{array}$ \\
\hline Foreign banks penetration & $\begin{array}{l}\text { Foreign banks' penetration in terms of an asset (FS) } \\
\text { or in terms of number (FN) }\end{array}$ & $\begin{array}{l}\text { Global Financial Development } \\
\text { Database (2019) }\end{array}$ \\
\hline CDI & Depth of information sharing factor & The World Bank \\
\hline CR5 & The 5-bank concentration ratio & $\begin{array}{l}\text { Global Financial Development } \\
\text { Database (2019) }\end{array}$ \\
\hline GDP per capita & GDP per capita (current US\$) & The World Bank \\
\hline Activity restrictions & $\begin{array}{l}\text { Capture banks' potential to engage in securities, } \\
\text { insurance, and real estate activities }\end{array}$ & $\begin{array}{l}\text { Barth, Caprio and Levine (2000, 2008, } \\
\text { and 2013) }\end{array}$ \\
\hline Stock Market Capitalisation & $\begin{array}{l}\text { The total value of all listed shares in a stock market } \\
\text { as a percentage of GDP (SMC) }\end{array}$ & $\begin{array}{l}\text { Global Financial Development } \\
\text { Database (2019) }\end{array}$ \\
\hline
\end{tabular}

The alternative proxy for banking competition is the Boone Indicator, which is a measure of the degree of competition obtained by calculating the elasticity of profits to marginal costs. To obtain the elasticity, the log of profits (measured by return on assets) is regressed on the log of marginal costs. This variable is the structural method relying on the efficiency hypothesis developed by Demsetz (1973). The most important aspect of the Boone indicator is related to demonstrating how insistent are the more efficient banks on using the advantages of their costs and distributing profits only by the efficient banks in the market. The Boone indicator indicated that the competition improved the performance of efficient firms and decreased the performance of the inefficient firms concentrating on the efficiency's impact to the performance in terms of profit and firm's market shares. The rationale behind the indicator is that higher profits are achieved by more efficient banks. Hence, the more negative the Boone indicator, the higher the degree of competition there is because the effect of reallocation is stronger.

Foreign bank penetration is defined as the increase in the size or number of foreign bank ownership throughout the banking sector in developing countries. It can be measured in two ways (Claessens and Leaven, 2004): as the ratio of the number of foreign banks to the total number of banks $(F N)$ in each country and year (Foreign Banks/ Total Number of Banks) and the share of the foreign bank assets over the total banking assets $(F S)$ in each country and year (Foreign Bank Assets/ Total Banking Assets).
A considerable amount of literature asserts that foreign ownership refers to control the business or resource by adopting the majority or complete foreigner ownerships. Thus, foreign individuals must acquire at least 50 percent of a bank's capital ownership to control bank operations and policies (Yeyati \& Micco, 2007; Jeon et al., 2011). The foreign bank penetration variables originate from countrylevel data of the GFDD in 2019.

We employ the 5-banks concentration ratio (CR5) to capture features of market structure. This variable takes a pivotal position in explaining the competitive environment (Bikker \& Haaf, 2002). In the empirical literature, most authors employed the k-bank concentration ratio. The k-bank concentration ratio is divided into two types, such as the threebank and five-bank ratios. This ratio refers to the fraction of assets held by the $\mathrm{k}$ largest commercial banks in a particular banking market in the range from zero to one hundred percent. This means that a high ratio represents the highly concentrated banking sector. The impact of concentration ratios on market power is ambiguous in accordance with empirical studies. Bikker and Haaf (2002) found out the significantly positive effect of concentration on competition. However, Claessens and Laeven (2004) found a significantly negative impact in this trend. Besides, Yeyati and Micco (2007) established that the concentration did not reduce competition in the banking sectors. This study uses the common ratio used in a majority of empirical studies: the 5-bank concentration ratio. The source of this variable is GFDD in 2019. 
According to Bresnahan (1989), the institutional details at the industry level will affect firms' conduct and it is also expected to affect banking system performance. In the empirical literature, this variable is likely to control the role of the quality of the country. Several indices of institutional framework are used in this and effect competition by changing the scope of moral hazard and adverse selection. In this term, this study uses the depth of information sharing indicator $(C D I)$ to capture the difference in information between public or private credit registries, rules affecting quality, scope, and accessibility of credit information. It is necessary to support a well-functioning and modern banking system (Miller, 2000). This index is laid between 0 and 6 . Higher values of this index show the availability of more credit information through a public or private registry and will help to reduce adverse selection and moral hazard problems to facilitate lending decisions (Pagano \& Jappelli, 1993; Kallberg \& Udell, 2003; Beck et al., 2013). The index used for this is derived from The World Bank.

The variable of activity restrictions index is used to measure bank regulation and supervision. It measures the degree to which national regulatory authorities allow banks to engage in securities, insurance, real estate businesses and non-financial ownership. The index values range from 1 to 4 , where larger values indicate more restrictions on banks performing each activity. In particular, 4 signifies prohibited, 3 indicates that there are tight restrictions on the provision of the activity, 2 means that the activity is permitted but with some limits, and 1 signals that the activity is permitted. The source of this index is Barth, Caprio and Levine (2000, 2008, and 2013).

Stock market capitalization rate is used to describe competition coming from inter-industry to investigate the impact of the degree of competition banks face from capital markets. It is calculated by the total value of all listed shares in a stock market as a percentage of GDP. The ratio compares the value of all stocks at an aggregate level to the value of the country's total output. Beck et al. (2006) used this variable as a proxy for the inter-industry variable. This variable is expected to capture the effect of competition from the non-banking financial sector on banking competition. In consequence, a highly developed stock market is likely capable of providing business enterprises with such an opportunity to create more funds directly than can obtain funds in banks. When the role of a bank to mobilize the savings from the non-financial sector is declined, they have a high incentive to compete more for keeping their own customers. This variable is deducted from The World Bank.

GDP per capita is gross domestic product divided by mid-year population. Data are in current US dollars. This variable comes from The World Bank Development Indicators.

\section{Results and Discussion}

The consistency of the GMM estimator depends on two specification tests. First is the Sargan test of over-identifying restrictions to checks the validity of instruments. The second test is the autocorrelation test (or called Arellano-Bond test) to check the assumption of no serial correlation found in the error terms (Arellano \& Bond, 1991). Failure to reject the null of both tests provides support to the estimated models. The Sargan test shows that the estimated equations are not over-identified, and the AR2 test shows there is no secondorder autocorrelation.

We use Cook's distance test (Cook \& Weisberg, 1982) to remove the possible effect of outlier observations on the estimation results. The presence of outliers will influence the estimation results once a single or a small group of observations makes a large difference in the results. The test is used to measure the impact of an individual observation on the estimated regression coefficient (Neter et al., 1985). The higher value of test statistic is the more influential corresponding observation on the regression coefficient. Cook and Weisberg (1982) consider observations with a value above one to be influential points. However, other scholars (Blatná, 2006) use a more conservative cut-off criterion of $4 / \mathrm{N}$, where $\mathrm{N}$ is the number of observations. Accordingly, this study takes the conservative approach and use $4 / \mathrm{N}$ as a cut-off point. The test suggests 15 potential outlier countries in different times namely, El Salvador $(\mathrm{t}=4)$, Hong Kong SAR, China $(\mathrm{t}=1,2,3)$, Indonesia $(\mathrm{t}=1)$, Panama $(t=1,2)$, Singapore (completely), and Turkey $(\mathrm{t}=3)$. Figure 1 provides a graphical view of the possible impact of individual countries on the estimated result. The figure shows the value of leverage point versus normalized residual squared. The potential outlier is the one with a high combination of leverage and residual.

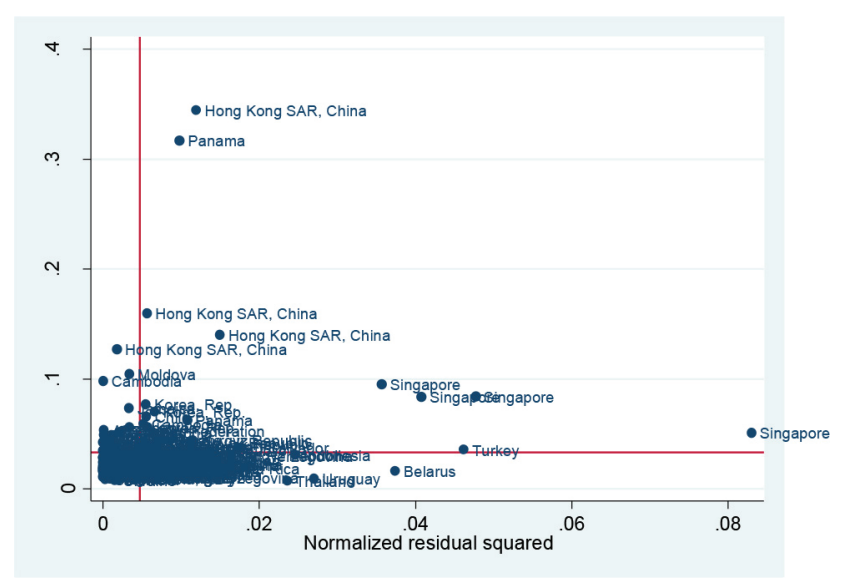

Figure 1: Identification of Outliers (including Lerner Index) 
The results of system GMM estimation as shown in Table 2 reveal that FS is insignificant. This result is consistent with some prior findings, which also find that FS has no direct effect on the Lerner index. On other control variables, only CDI, activity restriction and LGDP per capita are found to be insignificant at the usual level. More importantly, the results of the specification test show that the p-values of second serial correlation (i.e., AR (2)) and Sargan over-identification tests are big enough to accept the nulls. Therefore, the model is correctly specified and remove simultaneity bias are valid.

The next step of the analysis is to establish the contingency competition-effect of FS by estimating a linear interaction model using an interaction term constructed as foreign banks penetration in terms of asset and the CDI index $(\mathrm{FS} \times \mathrm{CDI})$. Within this specification, the contingency impact is measured based on the coefficient on the interaction term. If the term is found to be positive and significant, this implies that the effect of FS on the Lerner index increases with CDI. However, this modeling strategy should be carefully implemented; the addition of an interaction term may lead to multicollinearity problems. Based on Darlington (1990), including the interaction term into the model introduces the likelihood of a multicollinearity problem between regressors.

Consequently, this problem causes some independent variables to drop in the GMM procedure. To solve this kind of problem, Burrill (1997) suggested using the error term of interaction series instead of simply multiplying variables together. Therefore, we use the residual of interaction series in the model instead of using the two-step procedure as follows: First, the interaction terms are regressed on the foreign banks' penetration (in terms of assets or numbers) and depth of information sharing index. Second, the residuals saved from regression in the first step are used to represent the interaction term (Burrill, 1997). Consequently, we consider the interaction term foreign banks' penetration to be an asset with $\mathrm{CDI}$, as shown by (FS $\times \mathrm{CDI})$ and the interaction of foreign banks' penetration in terms of number with CDI shown by $(\mathrm{FN} \times \mathrm{CDI})$.

The results are presented in Table 3. A value of the lagged depended coefficient between 0 and 1 implies that the dependent variables of the above equations persist. However, they will eventually return to their normal (average) level.
Table 2: The Estimation Results of the Two-Step System GMM (No interactive variable)

\begin{tabular}{|l|c|c|c|}
\hline & Coef. & Std. Err. & p-value \\
\hline Lerner Index $_{\text {t-1 }}$ & 0.37 & 0.16 & $0.02^{* *}$ \\
\hline CR5 & 0.00 & 0.00 & $0.09^{*}$ \\
\hline FS & 0.00 & 0.00 & 0.34 \\
\hline CDI & -0.01 & 0.00 & 0.20 \\
\hline Activity restriction & 0.00 & 0.00 & 0.46 \\
\hline SMC & -0.00 & 0.00 & $0.00^{* * *}$ \\
\hline Log GDP per capita & -0.03 & 0.02 & 0.19 \\
\hline Constant & 1.15 & 0.26 & $0.00^{* * *}$ \\
\hline $\begin{array}{l}\text { Arellano-Bond Test for } \\
\text { AR (2) } \\
\text { (p-value) }\end{array}$ & 0.85 & & \\
\hline $\begin{array}{l}\text { Sargan Test } \\
\text { (p-value) }\end{array}$ & 0.56 & & \\
\hline
\end{tabular}

Notes: Robust standard error. Lerner Index as a proxy for competition. Foreign banks' penetration in terms of an asset (FS) as a proxy for foreign banks. CR5 as the 5-banks concentration ratio. Activity restriction as a proxy for contestability. SMC is the stock market capitalisation. Log GDP per capita as a proxy of economic development. P-value will be significant as follows: * $10 \%$ Significance level; ** $5 \%$ Significance level; and *** $1 \%$ Significance level.
Table 3: The Estimation Results of the Two-Step System GMM (The inclusion of Interactive variable $F S^{*} \mathrm{CDI}$ )

\begin{tabular}{|l|c|c|c|}
\hline & Coef. & Std. Err. & p-value \\
\hline Lerner Index $_{t-1}$ & 0.39 & 0.15 & $0.01^{* *}$ \\
\hline CR5 & 0.00 & 0.00 & $0.06^{*}$ \\
\hline$F S$ & 0.00 & 0.00 & 0.42 \\
\hline$C D I$ & -0.01 & 0.00 & 0.18 \\
\hline$\left(F S^{*} C D I\right)$ & 0.00 & 0.00 & $0.04^{* *}$ \\
\hline Activity restriction & 0.00 & 0.00 & 0.41 \\
\hline SMC & -0.00 & 0.00 & $0.00^{* * *}$ \\
\hline Log GDP per capita & 0.02 & 0.02 & 0.34 \\
\hline Constant & 1.02 & 0.25 & $0.00^{* * *}$ \\
\hline $\begin{array}{l}\text { Arellano-Bond Test for } \\
\text { AR (2) } \\
\text { (p-value) }\end{array}$ & 0.87 & & \\
\hline $\begin{array}{l}\text { Sargan Test } \\
\text { (p-value) }\end{array}$ & 0.59 & & \\
\hline
\end{tabular}

Notes: Robust standard error. Lerner Index as a proxy for competition. Foreign banks' penetration in terms of an asset (FS) as a proxy for foreign banks. CR5 as the 5-banks concentration ratio. Activity restriction as a proxy for contestability. SMC is the stock market capitalisation. Log GDP per capita as a proxy of economic development. P-value will be significant as follows: * $10 \%$ Significance level; ** $5 \%$ Significance level; and *** $1 \%$ Significance level. 
The results show that the coefficient on foreign banks penetration terms of an asset (FS) is insignificant. In other words, this variable has no direct effect on the Lerner index. Regarding other control variables, some variables such as activities restrictions, GDP per capita and CDI are found to be insignificant. The results of the specification test like the Arellano-Bond test and Sargan test show that both accept the null hypothesis. Therefore, the model is correctly specified and remove simultaneity bias are valid.

One must keep in mind that the Lerner index is an inverse measure of competition, meaning that a greater Lerner index means lower competition. The findings are in contrast with the three existing studies on this issue (Claessens \& Laeven, 2004; Jeon, et al., 2011) that document a positive effect of foreign bank presence level of competition measured at the country level. On the contrary, the result of Yeyati and Micco (2007) showed that foreign penetration weakened banking competition. According to literature, increased foreign bank presence can increase the market power of banks or intensify competition due to their comparative advantages and access to the new technology. Therefore, they offer a less risky and newer product compared to domestic banks.

In this analysis, the interaction term is constructed as foreign banks' penetration in terms of asset and the depth of information sharing index (CDI) is a proxy for institutional quality $(\mathrm{FS} \times \mathrm{CDI})$. Within this specification, the contingency impact is measured based on the coefficient on the interaction term. If the term is found to be positive and significant, this will imply that the effect of foreign banks penetration on the Lerner index increases with the depth of information sharing. However, this modeling strategy should be carefully implemented because the addition of an interaction term may lead to multicollinearity problems. As mentioned before, we used the residuals instead of interaction terms to solve the problem (Burrill, 1997).

Based on the results of Table 3, the coefficients on interaction terms $(\mathrm{FS} \times \mathrm{CDI})$ are positive and insignificant. These findings confirm that foreign banks' penetration in terms of an asset does not affect the Lerner index directly, but instead, its impact depends on the level of depth of information sharing as a proxy for institutional quality in the host country. That means any improvement in the depth of information sharing will facilitate better monitoring to give foreign banks more opportunity to increase the level of market power in banking sectors. The availability of more credit information will help to reduce adverse selection and moral hazard problems and encourage foreign banks to take on more level of market power. According to the literature, foreign banks tend to cherry-pick their customers and only provide financial services to high-margin clients in countries where institutions are weak and where they only have a relatively small share of the market. In this case, foreign banks' penetration can undermine access to financial services as it worsens the remaining credit pool available for domestic banks and will dampen banking competition.

Further, Table 3 shows that higher market concentration may dampen competition. Actually, we find that the coefficient on the banking concentration variable is positive in relation to the Lerner index. This is consistent with the structure-conduct performance (SCP) paradigm, which predicts an inverse relationship between concentration and competition. These results are consistent with those in Jeon et al. (2011) showing that positive coefficients imply higher concentration in the market for loans is associated with a lower level of banking competition. Other studies have reported empirical evidence that an increase in concentration does not necessarily mean reduced competition in the banking industry (e.g., Claessens \& Laeven, 2004; Wu et al., 2010).

To capture the difference in information between public or private credit registries on the credit-worthiness of borrowers and help reduce both adverse selection and moral hazard problems that are inherent to the lending business (Pagano \& Jappelli, 1993; Kallberg \& Udell, 2003), we employ the depth of information sharing as a proxy for institutional quality. The effect of this variable is negative and statistically insignificant. This suggests that countries with more availability of credit information through public or private registry enjoy lower levels of market power. In other words, banking competition will become more intensive.

Since the contestability theory predicts a direct relation between entrance barriers and competitiveness of the banking industry, we include in our model a variable that measures the contestability of the banking sector. We use an activity restrictions variable that measures the bank's ability to engage in the businesses of underwriting, insurance and real estate, as well as the regulatory allowance of banks to own shares in non-financial firms. A higher value of the activity restrictions variable indicates that more restrictions are imposed on cross-sector activities in the financial industry. The results show that market power is higher in countries that restrict banks from engaging in non-traditional activities (securities underwriting, real state, owning non-financial firms, and insurance). The coefficient on activity restriction is insignificant.

In terms of inter-industry competition, we employ the size of a country's stock market capitalization over GDP as an indicator of capital market development. According to Claessens and Laeven (2004), the more developed other parts of the financial sectors are, the more competitive pressure they impose on the banking system. The negative and significant coefficient on this variable confirmed their view. The results confirmed the results of Jeon et al. (2011). However, Claessens and Laeven (2004) did not find any evidence regarding the impact of the development of interindustry on the competitiveness of the banking system. 
Table 4: The Estimation Results of the Two-Step System GMM (Foreign banks' penetration in terms of number (FN) as a proxy of foreign banks' penetration)

\begin{tabular}{|l|c|c|c|}
\hline & Coef. & Std. Err. & p-value \\
\hline Lerner Index $_{t-1}$ & 0.75 & 0.27 & $0.00^{\text {*** }}$ \\
\hline CR5 & 0.00 & 0.00 & $0.07^{*}$ \\
\hline$F N$ & -0.00 & 0.00 & 0.16 \\
\hline$C D I$ & -0.03 & 0.01 & 0.43 \\
\hline$\left(F N^{*} C D I\right)$ & 0.00 & 0.00 & $0.01^{* *}$ \\
\hline Activity restriction & 0.00 & 0.00 & 0.43 \\
\hline SMC & -0.00 & 0.00 & $0.08^{*}$ \\
\hline Log GDP per capita & 0.04 & 0.04 & 0.32 \\
\hline $\begin{array}{l}\text { Arellano-Bond Test for } \\
\text { AR (2) } \\
\text { (p-value) }\end{array}$ & & 0.97 & \\
\hline $\begin{array}{l}\text { Sargan Test } \\
\text { (p-value) }\end{array}$ & & 0.14 & \\
\hline
\end{tabular}

Notes: Robust standard error. Lerner Index as a proxy for competition. Foreign banks' penetration in terms of number (FN) as a proxy for foreign banks. CR5 as the 5-banks concentration ratio. Activity restriction as a proxy for contestability. SMC is the stock market capitalisation. Log GDP per capita as a proxy of economic development. P-value will be significant as follows: * $10 \%$ Significance level; ${ }^{* *} 5 \%$ Significance level; and *** $1 \%$ Significance level.

Finally, in terms of the general level of development, we employ the GDP per capita. The positive and insignificant coefficient that shows economic development does not effect on Lerner indices directly.

\section{Robustness Test}

To test the robustness of the findings, we replace the proxy of foreign bank penetration; $F S$ with $F N$ (foreign bank penetration in term of number). When examining the robustness of the results, we only examine the impact of $C D I$, $F N$ and its interaction, ignoring the other variables. The results show that the coefficients on $F N$ and $C D I$ are insignificant and have no effect on the Lerner index. However, the coefficient of interaction term $(F N \times C D I)$ is positive and significant.

As another robustness check, we employ Boone Index as an alternative variable. The Boone Index is a measure of the degree of competition, calculated as the elasticity of profits to marginal costs. To obtain the elasticity, the log of profits (measured by return on assets) is regressed on the log of marginal costs.

As shown in Table 5, the interaction between FS and CDI remains robust. Thus, the ability of host countries
Table 5: The Estimation Results of the Two-Step System GMM (Boone Index as a proxy of competition)

\begin{tabular}{|l|c|c|c|}
\hline & Coef. & Std. Err. & p-value \\
\hline Boone Index $_{t-1}$ & 0.24 & 0.01 & $0.00^{* * *}$ \\
\hline CR5 & 0.00 & 0.00 & 0.84 \\
\hline FS & -0.00 & 0.00 & 0.45 \\
\hline CDI & -0.08 & 0.04 & $0.06^{*}$ \\
\hline$\left(F S^{*} C D I\right)$ & 0.00 & 0.00 & $0.09^{*}$ \\
\hline Activity restriction & 0.02 & 0.02 & 0.26 \\
\hline SMC & -0.00 & 0.00 & 0.93 \\
\hline IGDP per capita & 0.81 & 0.25 & $0.00^{* * *}$ \\
\hline Constant & -6.5 & 1.9 & $0.00^{* * *}$ \\
\hline $\begin{array}{l}\text { Arellano-Bond Test for } \\
\text { AR (2) }\end{array}$ & & 0.68 & \\
\hline Sargan Test (p-value) & & 0.31 & \\
\hline
\end{tabular}

Notes: Robust standard error. Boone Index as a proxy for competition. Foreign banks' penetration in terms of asset (FS) as a proxy for foreign banks. CR5 as the 5-banks concentration ratio. Activity restriction as a proxy for contestability. SMC is the stock market capitalisation. Log GDP per capita as a proxy of economic development. P-value will be significant as follows: * $10 \%$ Significance level; ** $5 \%$ Significance level; and *** $1 \%$ Significance level.

to derive benefits from FS can be significantly affected by the level of CDI. This provides further support to the importance of CDI for the FS-competition link. The positive effect of the interaction term shows that if the market has a high degree of coordination or collusion, or foreign banks are competing related to the quality of their products, they impose higher competition in the host market.

\section{Conclusion}

Banking sectors in developing countries are becoming increasingly international, and understanding the impact of foreign bank penetration on domestic banking sectors is becoming crucial. The literature on this subject shows varying results, with some arguing a positive effect on domestic banking sectors, and others a negative effect. In this regard, we are concerned with the impact of foreign bank penetration on competition in the domestic banking sectors in developing countries and the importance of regulatory and institutional quality on the banking environment. In this regard, the results will be crucial for the majority of developing countries, which often suffer from weak supervision and a flawed institutional framework. 
The results show that the effect of foreign bank penetration on competition depends on the depth of information sharing of the host country. There is good reason to investigate and analyze the impact of foreign banks on host competitive structure and to analyze the various influences that have changed or affected this link. Theoretical arguments have shaped the interaction between foreign bank penetration and the depth of information sharing of the host country. The results show that any improvement in the depth of information sharing of a host country will help foreign banks to improve monitoring and reduce the moral hazard and adverse selection problem, and encourage foreign banks to take on more level of market power. In this regard, foreign banks take steps to get more power and increase the level of market power.

According to literature, foreign banks tend to cherrypick their customers and only provide financial services to high-margin clients in countries where the availability of information about the customers is low and where they only have a relatively small share of the market. In this case, foreign banks penetration can undermine access to financial services as it worsens the remaining credit pool available for domestic banks and will dampen the banking competition.

When we employ the Boone indicator as an alternative dependent variable, the positive effect of the interaction term shows that foreign banks can impose higher competition on the host market due to the high degree of collusion or comparative advantage by having and improving in the quality of their products. Therefore, more efficient foreign banks can gain higher profits.

\section{References}

Agoraki, M.E., Delis, M., \& Pasiouras, F. (2011). Regulations, competition and bank risk-taking in transition countries. Journal of Financial Stability, 7(1), 38-48.

Arellano, M., \& Bond, S. (1991). Some tests of specification for panel data: Monte Carlo evidence and an application to employment equations. The Review of Economic Studies, 58(2), 277-297.

Blatná, D. (2006). Outliers in regression. Trutnov, 30, 1-6.

Barth, J. R., Caprio Jr, G., \& Levine, R. (2001). Banking systems around the globe: do regulation and ownership affect performance and stability? In Prudential supervision: What works and what doesn't (pp. 31-96). Chicago, IL: University of Chicago Press.

Barth, J. R., Caprio, G., \& Levine, R. (2008). Rethinking bank regulation: Till angels govern. Cambridge, MA: Cambridge University Press.

Barth, J. R., Caprio Jr, G., \& Levine, R. (2012). Guardians of finance: Making regulators work for us. Cambridge, MA: MIT Press.
Barth, J. R., Caprio, G., \& Levine, R. (2013). Bank regulation and supervision in 180 countries from 1999 to 2011. Journal of Financial Economic Policy, 5, 111-220.

Beck, T., De Jonghe, O., \& Schepens, G. (2013). Bank competition and stability: cross-country heterogeneity. Journal of Financial Intermediation, 22(2), 218-244.

Beck, T., Demirgüç-Kunt, A., \& Levine, R. (2006). Bank concentration, competition, and crises: First results. Journal of Banking \& Finance, 30(5), 1581-1603.

Beck, T., Ioannidou, V., \& Schäfer, L. (2018). Foreigners vs. Natives: Bank lending technologies and loan pricing. Management Science, 64(8), 3792-3820.

Berger, A. N., Klapper, L. F., \& Turk-Ariss, R. (2009). Bank competition and financial stability. Journal of Financial Services Research, 35(2), 99-118.

Bikker, J. A., Shaffer, S., \& Spierdijk, L. (2012). Assessing competition with the Panzar-Rosse model: The role of scale, costs, and equilibrium. Review of Economics and Statistics, 94(4), 1025-1044.

Bikker, J. A., \& Haaf, K. (2002). Competition, concentration and their relationship: An empirical analysis of the banking industry. Journal of Banking \& Finance, 26(11), 2191-2214.

Bresnahan, T. F. (1989). Empirical studies of industries with market power. Handbook of Industrial Organisation, 2, 10111057.

Burrill, D. F. (1997). Modeling and interpreting interactions in multiple regression. The Ontario Institute for Studies in Education Toronto, Ontario Canada.

Choi, J. Y., \& Kim, S. H. (2020). A Study on Organizational Forms in Foreign Expansion of Korean Banks. Journal of Asian Finance, Economics and Business, 7(7), 343-348. https://doi. org/10.13106/jafeb.2020.vol7.no7.343

Claessens, S., \& Laeven, L. (2004). What drives bank competition? Some international evidence. Journal of Money, Credit and Banking, 563-583.

Claessens, S., \& Van Horen, N. (2012). Foreign Banks: Trends, Impact and Financial Stability. Washington, DC: International Monetary Fund.

Claessens, S. (2017). Global banking: Recent developments and insights from research. Review of Finance, 21(4), 15131555.

Clarke, G., Cull, R., \& Peria, M.S.M. (2002). How does foreign bank participation affect access to credit by SMEs? Evidence from survey data. World Bank Working Paper.

Cook, R. D., \& Weisberg, S. (1982). Criticism and influence analysis in regression. Sociological Methodology, 13, 313-361.

Darlington, R. B. (1990). Regression and linear models. New York, NY: McGraw-Hill College. 
Demirguc-Kunt, A., \& Pería, M.S.M. (2010). A framework for analysing competition in the banking sector: an application to the case of Jordan. Washington, DC: The World Bank.

Demsetz, H. (1973). Industry structure, market rivalry, and public policy. The Journal of Law and Economics, 16(1), 1-9.

Goddard, J., \& Wilson, J.O. (2009). Competition in banking: a disequilibrium approach. Journal of Banking \& Finance, 33(12), 2282-2292.

Gormley, T. A. (2007). Costly information, foreign entry, and credit access. Unpublished paper, Olin Business School, Washington University, St. Louis.

Jappelli, T., \& Pagano, M. (2002). Information sharing, lending and defaults: Cross-country evidence. Journal of Banking \& Finance, 26(10), 2017-2045.

Jeon, B. N., Olivero, M. P., \& Wu, J. (2011). Do foreign banks increase competition? Evidence from developing Asian and Latin American banking markets. Journal of Banking \& Finance, 35(4), 856-875.

Kallberg, J. G., \& Udell, G. F. (2003). The value of private sector business credit information sharing: The US case. Journal of Banking \& Finance, 27(3), 449-469.

Miller, M. (2000). Credit reporting systems around the globe: the state of the art in public and private credit registries. Credit reporting systems and the international economy. Cambridge, MA: MIT Press.
Neter, J., Wasserman, W., \& Kutner, M. H. (1985). Applied linear statistical models: Regression. Analysis of Variance, and Experimental Designs (2nd ed.). Homewood, IL: Richard D. Irwin.

Pagano, M., \& Jappelli, T. (1993). Information sharing in credit markets. The Journal of Finance, 48(5), 1693-1718.

Pisedtasalasai, A., \& Edirisuriya, P. (2020). Diversification and Performance of Sri Lankan Banks. Journal of Asian Finance, Economics and Business, 7(9), 1-10. https://doi.org/10.13106/ jafeb.2020.vol7.no9.001

Purwono, R., Nugroho, R. Y. Y, \& Mubin, M. K. (2019). Response on New Credit Program In Indonesia: An Asymmetric Information Perspective. Journal of Asian Finance, Economics and Business, 6(2), 33-44. https://doi.org/10.13106/jafeb.2019. vol6.no2.33

Sengupta, R. (2007). Foreign entry and bank competition. Journal of Financial Economics, 84(2), 502-528.

Song, I. (2004). Foreign bank supervision and challenges to developing market supervisors. IMF Working Paper No. 04/82. Washington DC: IMF.

Wu, J., Jeon, B. N., \& Luca, A. C. (2010). Foreign bank penetration, resource allocation and economic growth: evidence from developing economies. Journal of Economic Integration, 25(1), 167-193.

Yeyati, E. L., \& Micco,A. (2007). Concentration and foreign penetration in Latin American banking sectors: Impact on competition and risk. Journal of Banking \& Finance, 31(6), 1633-1647. 